Jurnal Viabel Pertanian Vol. 13 No. 2 Nopember 2019

p-ISSN: 1978-5259 e-ISSN: 2527-3345

Copyright@UNISBA Blitar, http://ejournal.unisbablitar.ac.id/index.php/viabel

Dyah Pitaloka, Talifatim M., Anggraeni Hadi P., Risfa Nurrohman \& Evi Dwi Safitri 2019.

Teknik Konservasi Lahan Menggunakan Metode Kanopi Tanaman Labu Siam (Sechium edule) Di Desa

Sumber Brantas Batu Malang Journal Viabel Pertanian. (2019), 13(2)36-40

\title{
TEKNIK KONSERVASI LAHAN MENGGUNAKAN METODE KANOPI TANAMAN LABU SIAM (Sechium Edule) DI DESA SUMBER BRANTAS BATU MALANG
}

\author{
${ }^{1)}$ Dyah Pitaloka ${ }^{2)}$ Talifatim M. ${ }^{3)}$ Anggraeni Hadi P. ${ }^{4)}$ Risfa Nurrohman ${ }^{5)}$ Evi Dwi Safitri \\ ${ }^{1,2,3)}$ Dosen Fakultas Saintek Unira, ${ }^{4,5}$ Mahasiswa Fakulatas Saintek Unira \\ Email : ${ }^{1)}$ dyahpit88@yahoo.com ${ }^{2)}$ talifatim@uniramalang.ac.id ${ }^{3)}$ anggraeni.hp@ gmail.com \\ ${ }^{4)}$ lifarahman39@gmail.com ${ }^{5)}$ evikajossy@gmail.com
}

\begin{abstract}
Chayote (Sechiumedulesp) is gourd family (Cucurbiatea), this plant leaves tightly closed the planting area, grows on the ground or rather climbs, and is usually cultivated in the yard.Land conservation using the canopy cover method is one of the efforts made to save the environment.The change of land stretch from closed forest to open agricultural area and residential area in Tulungrejo Village, BumiadjiSubdistrict, Batu City is potential land degradation due to erosion caused by extreme rainfall due to the impact of climate change.

This study aims to determine the difference in the amount of erosion caused by rain wateron open land and closed land conservation using the Chayote plant canopy.This research was conducted from September to December 2018. The research location was in Tulungrejo Village, BumiadjiBatu District, East Java.The study began by making a 1x1 m2 water-holding pot in an open areaand areas with canopy cover of Chayote plants. The treatment in this study was repeated three times, with 5 duration of rain each 15 minutes later. The treatments were $\mathrm{E} 1=30$, minutes, $\mathrm{E} 2=45$ minutes, $\mathrm{E} 3=60$ minutes, $\mathrm{E} 4=75$ minutes and $\mathrm{E} 5=90$ minutes.

The results showed significantly different at E5,the treatment of rain simulation for 90 minutes duration in an open area without canopy cover of the conjoined Chayote plant, the highest erosion reaches $121 \mathrm{~kg} /$ ha, while the area using land cover with canopy of Chayote plant statistic showed a significant difference in all treatments with the amount of erosion in the duration of 90 minutes $89 \mathrm{~kg} / \mathrm{ha}$.
\end{abstract}

Keywords: Erosion, conservation, chayote

\section{Pendahuluan}

Kota Batu, kususnya Kecamatan Bumiaji berperan sebagai daerah penyangga resapan air tanah sesuai dengan Rencana Tata Ruang Wilayah yang disusun dari tahun 2009 sampai dengan 2029 (Tatag M., 2016). Desa Tulungrejo merupakan salah satu wilayah titik kritis Kecamatan Bumiaji,Kota Batu, karena dengan adanya bukaan areal lahan hutan menjadi lahan perumahan penduduk dan hortikultura. Dampak adanya perubahan iklim menyebabkan peningkatan rerata suhu harian dan hujan ekstrim, sehingga sebagian besar lahan di desa ini yang mengalami perubahan tata guna lahan yaitu dari perkebunan apel menjadi areal pertanian hortikultura mengalami degadrasi akibat pola tanaman yang kurang tepat. Kartosapoetro (2002) menegaskan, bahwa iklim berpengaruh terhadap konservasi tanah dan tanaman.

Erosi tanah ialah penyumbang terbesar terjadinya kerusakan lahan(Rudi H., 2016). Air hujan merupakan salah satu faktor penyebab erosi tanah, hujan ekstrim yang terjadi karena dampak perubahan iklim membawa dampak langsung berupa penurunan produktivitas lahan, dan produktivitas tanaman. 
Jurnal Viabel Pertanian Vol. 13 No. 2 Nopember 2019

p-ISSN: 1978-5259 e-ISSN: 2527-3345

Copyright@UNISBA Blitar, http://ejournal.unisbablitar.ac.id/index.php/viabel

Dyah Pitaloka, Talifatim M., Anggraeni Hadi P., Risfa Nurrohman \& Evi Dwi Safitri 2019.

Teknik Konservasi Lahan Menggunakan Metode Kanopi Tanaman Labu Siam (Sechium edule) Di Desa

Sumber Brantas Batu Malang Journal Viabel Pertanian. (2019), 13(2)36-40

Produktivitas tanah menurun karena hilangnya tanah lapisan olah atas yang merupakan bagian yang subur dan berfungsi sebagai pencengkeram akar tanaman.Degradasi lahan juga berdampak tidak langsung menyebabkan terjadinya endapan lumpur pada waduk di hilir sungai.

Metode konservasi vegetative menggunakan tanaman Labu siam (Sechium edule sp) yang merupakan tanaman suku labu-labuhan, memiliki beberapa kelebihan yaitu mempunyai kanopi rapat, tumbuh agak memanjat dan biasanya di budidayakan di pekarangan. Bentuk kanopi yang rapat pada tanaman labu siam mempunyai potensi sebagai pemotong pukulan air hujan, sehingga kekuatan pukulan air hujan yang jatuh ke permukaan tanah menjadi lebih lemah, disamping itu juga menghambat aliran air permukaan (run off), serta meningkatkan daya serap air tanah.

Penggunaan metode vegetasi sebagai pelindung tanah dari erosi berfungsi menghambat laju aliran permukaan, menambah kelengasan tanah serta memperbaiki sifat fisik, biologi dan kimia tanah.

Tujuan penelitian ini ialah untuk mengetahui perbedaan besarnya erosi yang disebabkan air hujan pada lahan terbuka dan konservasi lahan tertutup menggunakan tutupan kanopi tanaman labu siyam.

\section{Metode Penelitian}

Penelitian ini dilakukan dengan metode eksperimen, dimana data yang diperoleh berasal dari uji lapangan di Desa Tulungrejo Kecamatan Bumiaji Kota Batu, yang kemudian dianalisa di Labolatorium Universitas Islam Raden Rahmat Malang. Pengambilan data Eksperimen ini dilakukan menggunakan hujan ekstensi selama enam hari, pada tanggal 6 sampai dengan 9 September 2018.

\section{Alat dan Bahan}

Alat yang digunakan pada penelitian ini ialah, Bak penampung, Spiringkel, Ombrometer, gelas ukur, talang penampung air, curigen, kertas saring, timbangan analitik dan oven.

Bahan yang digunakan ialah air, dan tanaman Labu Siam.

\section{Tahapan Penelitian}

Pengukuran Erosi lahan dilakukan pada 2 tempat yaitu pada lahan labu siam dan lahan kosong tanpa tutupan kanopi labu siam.

Pertama, melakukan pemasangan alat yang berupa ombro meter, jirigen, talang penyalur air, dan spiringkel. Pada lahan manisah spiringkel dipasang diatas tajuk manisah dan dibawah spiringkel dipasang ombrometer untuk melihat jumlah air yang tertampung pada selang waktu yang ditentukan.

Kedua, Spiringkel sebagai alat hujan buatan ditentukan selang waktu rentang 15 menit dengan 5 perlakuan diulang 5 kali pada kedua tempat lahan kosong dan lahan labu siam. Rentang waktu yang ditentukan sbb :

- 30 menit

- 45 menit

- 60 menit

- 75 menit

- 90 menit 
Jurnal Viabel Pertanian Vol. 13 No. 2 Nopember 2019

p-ISSN: 1978-5259 e-ISSN: 2527-3345

Copyright@UNISBA Blitar, http://ejournal.unisbablitar.ac.id/index.php/viabel

Dyah Pitaloka, Talifatim M., Anggraeni Hadi P., Risfa Nurrohman \& Evi Dwi Safitri 2019.

Teknik Konservasi Lahan Menggunakan Metode Kanopi Tanaman Labu Siam (Sechium edule) Di Desa

Sumber Brantas Batu Malang Journal Viabel Pertanian. (2019), 13(2)36-40

Ketiga, Air yang tertampung pada jirigen penampungdiukur kemuian di aduk dan diambil sebanyak 1 liter sebagai sampel setiap masing-masing perlakuan. Demikian pula, air yang tertampung didalam ombro meter di catat.

Mendiamkan air yang berada di dalam bakpenampung air selama 24 jam. Setelah 24 jam contoh air tersebut diambil menggunakan kertas saring. Terdapat masing-masing 25 sampel dari 2 perlakuan 5 taraf perlakuan masingdiulang 5 kali pada lahan Labu Siam dan lahan kosong pada 2 lokasi.

Analisa di Labolatorium

Pertama, memotong kertas wat man dengan ukuran $15 \mathrm{~cm}$ x $15 \mathrm{~cm}$ dan di oven hingga berat kering kertas mencapai 1 gr.

Kedua, Air yang terapat pada botol dengan ukuran 1 liter disaring menggunakan kertas watman dan hasil tanah yang tersaring diikat menggunakan tali raffia.

Ketiga, Berat basah ditimbang dengan menggunakan timbangan analitik 1 dijid

Keempat, Sampel dioven dengan suhu $100{ }^{\circ} \mathrm{c}$ selama 3 jam.

Kelima, Setelah di oven didiamkan sesaat,kemudian ditimbang dengan timbangan analitik 4 dijid dan dicatat beratnya.

\section{Hasil dan Pembahasan}

\section{Hasil}

Hasil dari penelitian ini disampaikan pada tabel sbb :

Tabel 1. Uji Erosi di lahan Terbuka

E1 0,053a

E2 $\quad 0,067 \mathrm{ab}$

E3 $0,081 \mathrm{abc}$

E4 $0,099 b c$

E5 $0,121 \mathrm{c}$

BNT 5\% 0,044

Pada Tabel 1, menunjukkan hasil uji statistic dengan uji BNT taraf 5\% pada lahan terbuka tanpa kanopi daun labu siam, dimana pada perlakuan E1 (durasi 30 menit) sampai dengan E4 (60 menit) tidak menunjukkan perbedaan yang nyata, dan pada perlakuan E2 (durasi 30menit) sampai dengan E4(durasi 75 menit) juga tidak menunjukkan perbedaanbesarnya laju erosi. Selanjutnya pada E3 ((durasi 45 menit) sd E5 (90 menit) juga tidak menunjukkan perbedaan nyata . 
Dyah Pitaloka, Talifatim M., Anggraeni Hadi P., Risfa Nurrohman \& Evi Dwi Safitri 2019.

Teknik Konservasi Lahan Menggunakan Metode Kanopi Tanaman Labu Siam (Sechium edule) Di Desa

Sumber Brantas Batu Malang Journal Viabel Pertanian. (2019), 13(2)36-40

Tabel 2. Uji Erosi di lahan Tertutup

T1 0,022a

T2 $0,035 b$

T3 $0,052 \mathrm{c}$

T4 $0,064 d$

T5 $0,089 \mathrm{e}$

BNT $5 \% \quad 0,002$

Pada table 2 menunjukkan bahwa tiap perlakuan dengan perbedaan durasi selang 15 menit menunjukkan perbedaan nyata, hasil tertinggi erosi ditunjukkan oleh perlakuan T5 durasi hujan 90 menit pada areal tertutup dengan area lahan menggunakan tutupan kanopi labu siam sebesar $89 \mathrm{~kg} / \mathrm{ha}$.

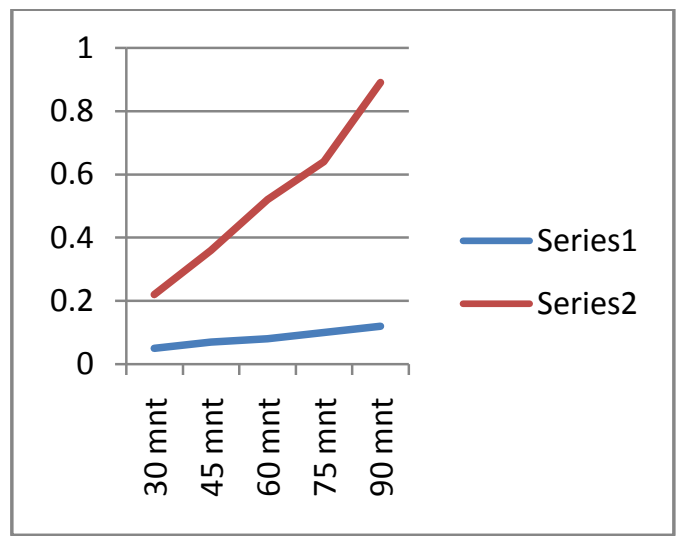

Gambar 1. Laju Erosi di lahan terbuka .

Dari gambar 1 menunjukkan hasiterjadi erosi yang dilahan terbuka (garis merah) dan areal lahan tertutup (garis biru). Erosi tertinggi ditunjukkan oleh erosi pada areal terbuka dengan durasi waktu hujan selama 90 menit.

\section{Pembahasan}

Konservasi ialah penempatan sebidang tanah pada setiap cara penggunaan yang disesuaikan dengan kemampuan tanah tersebut (Rusdi et al., 2013). Hasil penelitian menunjukkan bahwa erosi pada lahan yang terbuka tanpa tutupan kanopi labu siam menunjukkan angka erosi dengan nilai yang lebih tinggi, yang ditunjukkan pada perlakuan 90 menit durasi air hujan dengan hasil bobot tanah yang tererosi $121 \mathrm{~kg} / \mathrm{ha}$.

Sucipto (2007) menyampaikan, bahwa aliran erosi yang terjadipada lahan terbuka disebabkan oleh aliran permukaan. Energi kinetic air hujan yang jatuh mengenai permukaan ,menyebabkan agregat tanah terpecah. Pecahan agregat tanah yang halus tersebut masuk ke dalam pori tanah bersama infiltrasi air sehingga menutup ruang pori tanah. Kondisi tertutupnya pori tanah menyebabkan hambatan laju infiltrasi sehingga terjadilah aliran permukaan (run off) yang membawa lapisan tanah subur di bagian atas tanah.

Pada gambar 1 menunjukkan bahwa semakin lama durasi hujan baik pada areal yang tertutup kanopi (garis biru) ataupun pada areal tanah yang terbuka (garis merah)menunjukkan peningkatanjumlah tanah yang terbawa bersama limpasan air hujan. Pada areal yang terbuka 
Jurnal Viabel Pertanian Vol. 13 No. 2 Nopember 2019

p-ISSN: 1978-5259 e-ISSN: 2527-3345

Copyright@UNISBA Blitar, http://ejournal.unisbablitar.ac.id/index.php/viabel

Dyah Pitaloka, Talifatim M., Anggraeni Hadi P., Risfa Nurrohman \& Evi Dwi Safitri 2019.

Teknik Konservasi Lahan Menggunakan Metode Kanopi Tanaman Labu Siam (Sechium edule) Di Desa

Sumber Brantas Batu Malang Journal Viabel Pertanian. (2019), 13(2)36-40

tanpa tutupan kanopi (garis merah) menunjukkan jumlah erosi yang lebih tinggi dibanding dengan areal lahan yang menggunakan tutupan kanopi labu siam.

Pada gambar tersebut juga menunjukkan bahwa lamanya curah hujan juga berpengaruh secara signifikan dengan semakin tingginya erosi yang terjadi baik pada areal dengantertutup kanopi maupun areal terbuka, dimana menunjukkan trend yang meningkat sampai dengan perlakuan 90 menit lamanya tanah terguyur air.Djoko Santoso et al. (2008) dan Rifky et al. (2016) menyampaikan bahwa untuk keberlanjutan produktivitas lahan perlu dilakukan upaya konservasi tanah dan air serta mencegah hanyutnya humus tanah, partikel lembut dan bahan organic tanahserta seresah.Upaya tersebut dapat dilakukan dengan menggunakan teknik konservasi vegetative dan mekanik.Upaya konservasi tanah tidak hanya bertujuan untuk menanggulangi erosi serta aliran permukaan, namun konservasi juga menjaga kesuburan lahan pertanian. Penelitian ini menunjukkan jika labu siam yang mempuyai canopy rapat mempunyai potensi sebagai salah satu tanaman yang mempunyai peranan untuk menurunkan erosi tanah, dengan nilai erosi yang lebih rendah dibanding erosi pada lahan terbuka (tanpa naungan tanaman)

\section{Kesimpulan}

Hasil Penelitian menunjukkan bahwa areal terbuka tanpa tutupan canopy labu siam menunjukkan hasil erosi tertinggi dengan semakin meingkatnya durasi perlakuan hujan, berbeda nyata, yaitu pada durasi 90 menit simulasi hujan dengan besar erosi pada perlakuan E5 sebesar $121 \mathrm{~kg} / \mathrm{ha}$ dibandingkan dengan areal tertutup sebesar $89 \mathrm{~kg} / \mathrm{ha}$.

Tanaman labu siam mempunyai potensi sebagai tanaman pencegah erosi karena mempunyai kanopi yang rapat dimana berfungsi mengurangi laju pukulan air hujan yg jatuh ke permukaan lahan.

\section{Daftar Pustaka}

Djoko S., Joko P., I G. P. Wigena, Enggis T,. 2008. Teknologi Konservasi Tanah Vegetatif. Ballitanah Litbang Pertanian. https://id.search.yahoo.com/search;_ylt=AwrwJSfDPbhdt2oAv1z.ZHRG?p=teknologi+ko nservasi+lahan+menggunakan+tanaman+penelitian\&fr $2=$ sb-top \&fr=yfp-t\&fp $=1$, diunduh 29 Oktober 2019.

Kartasapoetra, A. 2002.Klimatologi Pengaruh Iklim terhadap Tanah dan Tanaman. Bumi Aksara, Jakarta.

Rudi H. 2016. Identifikasi Bentuk Erosi Tanah Melalui Interpretasi Citra Google Earth Di Wilayah Sumber Brantas Kota Batu .Jurnal Pendidikan Geografi, 21 (1)p: 30-42.

Rusdi, M. Rusli A., Abubakar K. The Evaluation of Land Degradation by Erosion in Agricultural Area at Lembah Seulawah Sub-distrik Aceh Besar. J. Manajemen Sumberdaya Lahan. 2(3) : p. 240-249

Tatag M., 2016. Pengertian Erosi serta Metode Konservasi Tanah Secara Lengkap.https://www.gurupendidikan.co.id/pengertian-erosi-serta-metode-konservasitanah-secara-lengkap.Diunduh tgl 22 Oktober 2019

Sucipto. 2007.Analisis Erosi Yang Terjadi Di Lahan Karena Pengaruh Kepadatan Tanah.Wahana Teknik Sipil 12 (1) p.51-60 